\title{
Unilateral leukonychia and hair depigmentation in multifocal motor neuropathy
}

Figure Unilateral leukonychia and hemibody hair depigmentation

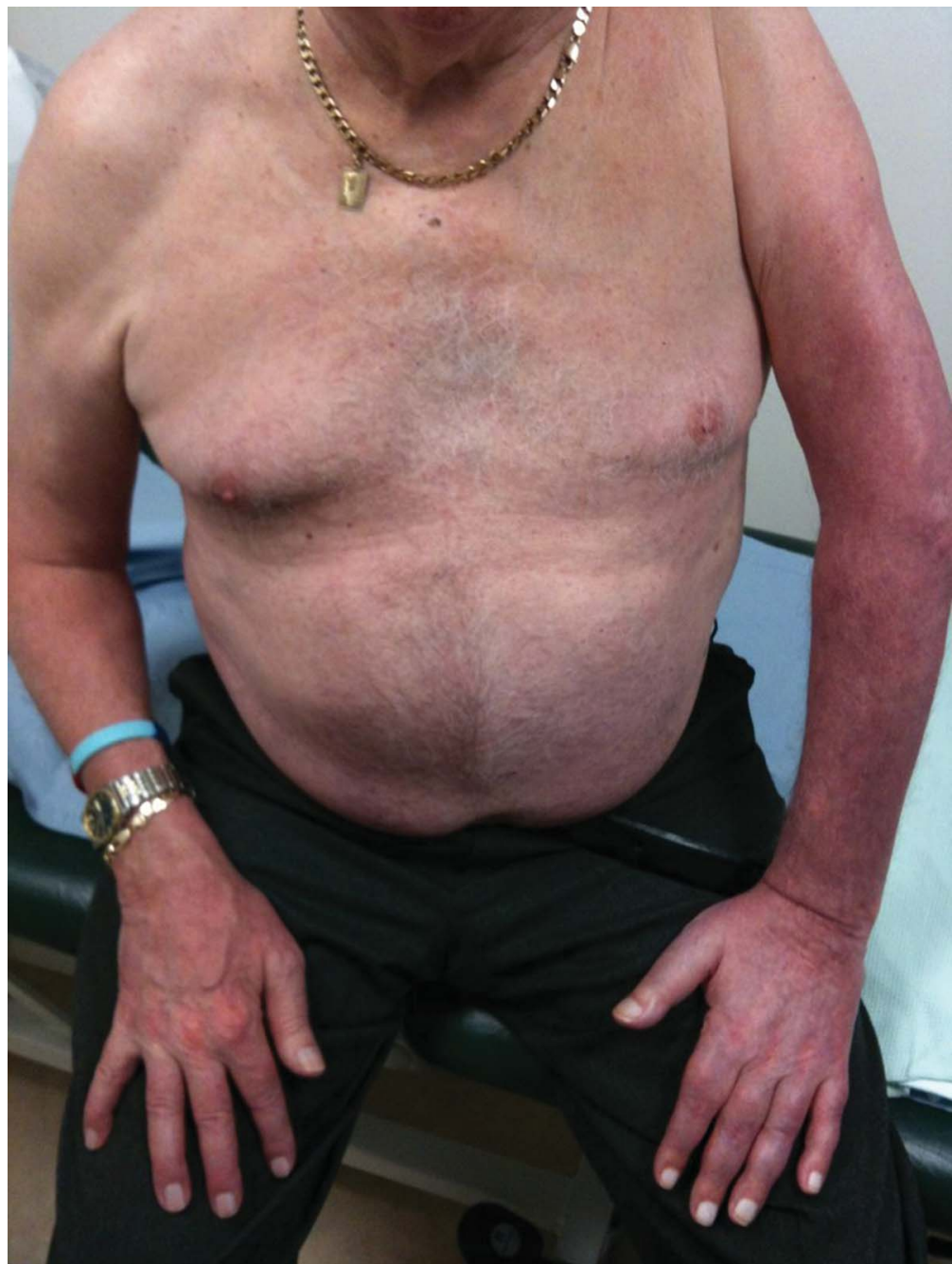

Patient (viewed from the front) shows unilateral left upper limb leukonychia with depigmentation of chest and abdominal hair and a clear midline demarcation. The left arm appears hyperemic in comparison. The hair depigmentation did not extend to the head or legs.

Neurophysiology studies in a 50-year-old man with slowly progressive weakness of the left upper limb revealed conduction block in the ulnar nerve above the elbow. His weakness remained stable with regular subcutaneous immunoglobulin, but he noted gradual hemibody hair depigmentation. Examination also revealed unilateral left hand leukonychia (figure). MRI of the brain and cervical spine was normal.

Multifocal motor neuropathy with conduction block is a rare autoimmune motor neuropathy typically presenting with asymmetric distal upper limb weakness without sensory loss. ${ }^{1}$ Unilateral nail changes have been described in the context of posttraumatic reflex sympathetic dystrophy. ${ }^{2}$ The hair depigmentation is unexplained.

Martin R. Turner, PhD 
From the University of Oxford Nuffield Department of Clinical Neurosciences, John Radcliffe Hospital, Oxford, UK.

Study funding: No targeted funding reported.

Disclosure: The author reports no disclosures relevant to the manuscript. Go to Neurology.org for full disclosures.

Correspondence to Dr. Turner: martin.turner@ndcn.ox.ac.uk

1. Vlam L, van der Pol WL, Cats EA, et al. Multifocal motor neuropathy: diagnosis, pathogenesis and treatment strategies. Nat Rev Neurol 2013;8:48-58.

2. Pucevich B, Spencer L, English JC 3rd. Unilateral trachyonychia in a patient with reflex sympathetic dystrophy. J Am Acad Dermatol 2008;58:320-322. 


\section{Neurology}

\section{Unilateral leukonychia and hair depigmentation in multifocal motor neuropathy \\ Martin R. Turner \\ Neurology 2013;81;1800-1801 \\ DOI 10.1212/01.wnl.0000435562.07857.fd}

\section{This information is current as of November 11, 2013}

Updated Information \&
Services

References

Subspecialty Collections

Permissions \& Licensing

Reprints including high resolution figures, can be found at: http://n.neurology.org/content/81/20/1800.full

This article cites 2 articles, 0 of which you can access for free at: http://n.neurology.org/content/81/20/1800.full\#ref-list-1

This article, along with others on similar topics, appears in the following collection(s):

\section{All Neuromuscular Disease}

http://n.neurology.org/cgi/collection/all_neuromuscular_disease Autoimmune diseases

http://n.neurology.org/cgi/collection/autoimmune_diseases Clinical neurology examination

http://n.neurology.org/cgi/collection/clinical_neurology_examination

Information about reproducing this article in parts (figures,tables) or in its entirety can be found online at:

http://www.neurology.org/about/about_the_journal\#permissions

Information about ordering reprints can be found online:

http://n.neurology.org/subscribers/advertise

Neurology ${ }^{\circledR}$ is the official journal of the American Academy of Neurology. Published continuously since 1951, it is now a weekly with 48 issues per year. Copyright () 2013 American Academy of Neurology. All rights reserved. Print ISSN: 0028-3878. Online ISSN: 1526-632X.

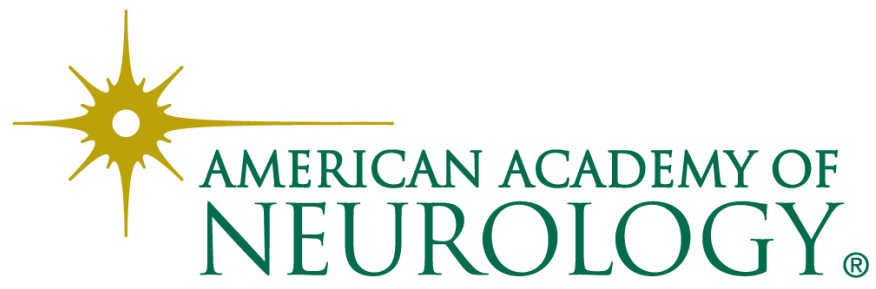

